\title{
DAIRY FARMERS' VIEWS ON ENVIRONMENT, RESULTS OF QUESTIONNAIRE SURVEY FROM REGIONS OF MAZOWSZE AND PODLASIE IN POLAND
}

\author{
Alina Syp ${ }^{1}$, Dariusz Osuch ${ }^{2}$ \\ ${ }^{1}$ Institute of Soil Science and Plant Cultivation Sate Research Institute, Poland; ${ }^{2}$ Institute of \\ Agricultural and Food Economics? National Research Institute, Poland \\ asyp@iung.pulawy.pl, dariusz.osuch@ierigz.waw.pl
}

\begin{abstract}
Intensive agricultural production has a negative impact on the environment. Therefore, almost thirty years ago, as a part of the Common Agricultural Policy (CAP), the Agri-environmental schemes (AES) were implemented. Since the first introduction, AES have been reconstructed and their budget increased. Despite these changes, many studies still show the negative impact of agricultural practices on the environment as an unresolved problem. The main reason for this is the inefficient implementation of AES by farmers. The greater knowledge and ecological awareness among farmers may facilitate the policy development. This paper presents a view of dairy farmers towards environmental threats in Poland, in the region of Mazowsze and Podlasie. The survey was conducted in 2017, in 20 dairy farms participating in AES and in 22 farms non-participating in AES. The results present that 91 and $75 \%$ non-AES and AES dairy farmers, respectively, declared the impact of own farm activity on the environment. However, a higher $\%$ of AES respondents stated that intensive agriculture has a negative impact on the environment. All risks to the environment were assessed as higher by AES farmers when compared to non-AES. For both groups of farmers the usage of high pesticide and fertilization doses has the most harmful effects on the environment. As much as $95 \%$ of the respondents from AES and non-AES farms stated that application of financial incentives may encourage farmers to implement solutions improving the state of the environment. The need to raise ecological awareness was the second factor reported by them. The attitude of non-AES farmers towards environmental regulations has been less positive than of AES farmers. The similar \% of respondents from both groups declared that it is important for them to manage farms without damaging the environment and to make a profit. The principal finding of our research shows that all the surveyed farmers were characterized by high environmental awareness.
\end{abstract}

Key words: dairy farms, environment, risk, survey.

\section{Introduction}

Expansion and intensification of agriculture are the most important drivers of biodiversity loss. Therefore, in 1992, the Agri-environment schemes (AES) were introduced into the Common Agricultural Policy (CAP). The aim of AES is to protect the environment in agricultural landscapes [1]. Since the first implementation of AES, the scope of applying friendly farming practices has increased, which resulted in the budget increase. The efficiency of AES schemes was assessed by many researchers and some of them claimed that effectiveness of AES is lower than planned [2;3]. Analysis of participation in AES in Europe has shown that personal factors were equally important to financial motivation [4]. Personal factors include values, attitudes, motivations and perceptions, and various social-psychological models and theories have been developed to explore and explain their influence on farmers' behaviour [5].The lack of success of AES implementation has been explained by insufficient understanding of how farmers perceive AES and their individual reasons for and against participation [6]. As farmers are the key to effectiveness of AES implementation, better knowledge about their views on environmental values can be very helpful for policy makersto further improve AES. This attitude is based on the assumption that farmers are a very heterogeneous society, think differently and have various approaches towards AES, thus, they need to be addressed accordingly. Batary et al. [2] stated that schemes applied after 2007 were not more effective than those applied before 2007. AES were effective in both periods but there was no sign of progress in efficiency over time. The aim of this study was to evaluate dairy farmers' views on environment in the region of Mazowsze and Podlasie in Poland.

\section{Material and methods}

The geographic area investigated in this study was the region ofMazowsze and Podlasie. The studied area is a part of the Farm Accountancy Data Network (FADN) and includes four voivodships, namely: Mazowieckie, Podlaskie, Lubelskie and Łódzkie. At the time the survey was carried out, the share of farmers from this region, who applied for AES payments, amounted to $35 \%$ of all applicants, and the requested amount represented $25 \%$ of the national quota [7]. In the selected area the utilized 
agricultural area (UAA) of the region represents $37.2 \%$ of the country's UAA and $48 \%$ of all cattle stocks [8]. The sample was constructed using the FADN database from the period of 2010-2015. The survey covered only dairy holdings, which were in the FADN system during the whole selected period. To be a dairy farmer (TF 5) based on EU standard classification of "Type of farming" (TF) [9]at least $66 \%$ of farmer's standard output must come from milk production. The study was done for two groups of farms. The first one included farms taking part in AES and the second - not participating in AES (non-AES). In this study 60 dairy farms were chosen to contribute in the survey. $50 \%$ of them were non-AES farms located as near as possible to AES farms. In order to gather information about the farmers' attitude towards environmental aspects, the authors developed a questionnaire. Then it was reviewed by social experts and agricultural advisors and next tested on a limited number of targeted farmers. Due to the fact that the sample comes from the FADN database, questions in the survey related to socio-demographic variable were omitted. It allowed to limit the number of questions and reduce the farmers' time dedicated to answering them. The survey consisted of five sections. The first four sections consisted of questions related to assessment of environmental awareness. The respondents were asked to answer "Yes", "No" or "I have no opinion". The last part of the survey included questions measuring the farmers' values related to environmental behaviour and attitude towards environmental regulations. The farmers stated their degree of agreement on a fivepoint Likert scale ( $1=$ strongly disagree and $5=$ strongly agree). The survey was conducted in 2017 , in the region of Mazowsze and Podlasie,in dairy farms through a face-to-face interview performed by agricultural advisors. The interviewers explained the questions to the farmers and directly wrote down their responses, which minimalised the risk of misunderstanding the Likert scale or the questions. Data from the received questionnaires were manually introduced into the excel database. The obtained data were analysed using descriptive statistics(the means and standard deviations). This research was carried our as a part of a larger study for the Ministry of Agriculture and Rural Development.

\section{Results and discussion}

\section{Representatives of the survey}

In this survey, the participation rate was 67\% (20 completed questionnaires) and $73 \%$ (22 completed questionnaires) for AES and non-AES dairy farms, respectively. Due to involvement of agricultural advisors from the Extension Services and the small sample of farms, the response rate was high. Schroeder et al. [6] obtained a similar response rate (73\%) for the sample of 44 holdings contacted via telephone. When the tested samples are larger and different distribution channels of surveys are used rather than the face-to face interviews, the percentage of answers slower. Using the online survey platform, Hejnowicz et al. [10] received $29.9 \%$ valid forms, whereas Woods et. al [11] $-36 \%$. In order to encourage respondents to participate in the survey some researchers offer them gifts $[12 ; 13]$.

\section{Descriptive statistics}

The descriptive statistics of the surveyed dairy holdings are presented in Table 1. All presented variables for non-AES dairy farms were higher compared to AES farms. In both types of farms the total assets were of high value. The average value of total assets of non-AES farms was by $6 \%$ higher than of AES farms, but the index of assets' productivity measure as a ratio of total output to total assets of these farms was by $3 \%$ higher. This shows that non-AES dairy farms were better managed. In Poland, after joining the European Union in 2004, there were substantial investments in dairy holdings due to necessary adjustments to market conditions.

Descriptive statistics of sample dairy farms in 2015

Table 1

\begin{tabular}{|c|c|c|c|}
\hline \multirow{2}{*}{ No } & \multirow{2}{*}{ General information } & \multicolumn{2}{|c|}{ Type of farms } \\
\cline { 3 - 4 } & & AES & Non AES \\
\hline 1 & Number of farms (SYS03) & 20 & 22 \\
\hline 2 & Economic size (SE005) (EUR) & 42717 & 47345 \\
\hline 3 & UAA (SE 025) (ha) & 33 & 36 \\
\hline 4 & Rented UAA (SE030) (ha) & 10.9 & 15.3 \\
\hline
\end{tabular}


Table 1 (continued)

\begin{tabular}{|c|c|c|c|}
\hline \multirow{2}{*}{ No } & \multirow{2}{*}{ General information } & \multicolumn{2}{|c|}{ Type of farms } \\
\cline { 3 - 4 } & & AES & Non AES \\
\hline 5 & No animals per farm (LU) & 34.1 & 38.6 \\
\hline 6 & Labour input (SE010) (AWU) & 1.93 & 1.98 \\
\hline 7 & Total output ((SE131)(PLN) & 161476 & 215437 \\
\hline 8 & Family farm income (SE 420)(PLN) & 62364 & 64319 \\
\hline 9 & Machinery (SE 455)(PLN) & 249270 & 277546 \\
\hline 10 & Total assets (SE 436)(PLN) & 1236412 & 1316997 \\
\hline
\end{tabular}

Notes: PLN - Polish currency, UAA - Utilised Agricultural Area, AWU - Annual Work Unit Source: authors' calculations based on the FADN data

\section{General perceptions towards the environment}

$91 \%$ of non-AES farmers declared opinions on their impact on the environment (Table 2). The share of AES farmers, who confirmed this statement, amounted to $75 \%$. However, up to $20 \%$ of AES dairy farmers did not have any opinion on this issue. The same percentage of respondents did not have an opinion about the negative impact of intensive agriculture on the environment (Table 3). But $80 \%$ of AES farmers expressed an opinion that intensive agriculture is not good for the environment. The obtained results present that AES dairy farmers, compared with non-AES farmers, are more aware of the negative impact of intensive agriculture on the environment. Both AES and non-AES dairy farmers believe that the greatest risk to the environment is created by using high doses of fertilizers and plant protection products (Table 4).

Table 2

According to your opinion, do you have an impact on the environment?" (\%)

\begin{tabular}{|c|c|c|c|}
\hline Farm types & Yes & No & I have no opinion \\
\hline AES Dairy & 75 & 5 & 20 \\
\hline Non AES Dairy & 91 & 9 & 0 \\
\hline
\end{tabular}

Source: authors' calculations based on the survey

Table 3

According to your opinion, do you think that intensive agriculture has a negative impact on the environment? (\%)

\begin{tabular}{|c|c|c|c|}
\hline Farm types & Yes & No & I have no opinion \\
\hline AES Dairy & 80 & 0 & 20 \\
\hline Non AES Dairy & 73 & 14 & 13 \\
\hline
\end{tabular}

Source: authors' calculations based on the survey

Table 4

According to your opinion, what is the highest risk to the environment? (\%)

\begin{tabular}{|c|c|c|c|c|c|c|}
\hline \multirow{2}{*}{ Items } & \multicolumn{3}{|c|}{ AES Dairy } & \multicolumn{3}{c|}{ Non AES Dairy } \\
\cline { 2 - 7 } & Yes & No & I have no opinion & Yes & No & I have no opinion \\
\hline $\begin{array}{c}\text { Intensification of crop } \\
\text { production }\end{array}$ & 45 & 35 & 20 & 41 & 14 & 45 \\
\hline High concentration of livestock & 75 & 10 & 15 & 73 & 0 & 27 \\
\hline High fertilization doses & 85 & 10 & 5 & 82 & 0 & 18 \\
\hline High pesticides doses & 95 & 0 & 5 & 86 & 0 & 14 \\
\hline Soil erosion & 55 & 25 & 20 & 45 & 14 & 41 \\
\hline Waste management & 50 & 15 & 35 & 59 & 14 & 27 \\
\hline Decline of biodiversity & 55 & 0 & 45 & 27 & 9 & 64 \\
\hline $\begin{array}{c}\text { Emissions of pollutants to the } \\
\text { atmosphere }\end{array}$ & 75 & 5 & 20 & 73 & 5 & 23 \\
\hline
\end{tabular}

Source: authors' calculations based on the survey 
The further threats to the environment are high concentration of livestock and emissions of pollutants to atmosphere. Intensification of crop production is seen as a lower risk to environment. AES farmers valued the impact of all factors on environment slightly higher compared to non-AES respondents. Nevertheless, the performed survey showed that environmental awareness is high among both types of farmers. Somewhat surprising, however, are the low scores (41-45\%) of the danger resulting from the intensification of crop production, despite the fact that application of high fertilization doses was seen as the highest risk to environment (82-85\%). It can result from the fact that the research was carried out in dairy farms, which focus mainly on intensification of milk production. The improper waste management was one factor, the risk of which was valued higher by non-AEA than AES farmers. Also, in both farm groups large number of people did not have an opinion on this threat. The results of our studies are in line with the research results found by Mroczek et al. [14].Concerning the measure to be taken to improve the state of environment, the application of financial incentives is the key for $95 \%$ respondents in each group (Table 5).

Table 5

According to your opinion, what should be done to improve the state of the environment? (\%)

\begin{tabular}{|c|c|c|c|c|c|c|}
\hline \multirow{2}{*}{ Items } & \multicolumn{4}{|c|}{ AES Dairy } & \multicolumn{3}{c|}{ Non AES Dairy } \\
\cline { 2 - 7 } & Yes & No & I have no opinion & Yes & No & I have no opinion \\
\hline Raiseecologicalawareness & 85 & 0 & 15 & 82 & 0 & 18 \\
\hline Applyfinancialincentives & 95 & 5 & 0 & 95 & 5 & 0 \\
\hline $\begin{array}{c}\text { Control and punish for } \\
\text { environmental pollution }\end{array}$ & 55 & 30 & 15 & 45 & 18 & 36 \\
\hline
\end{tabular}

Source: authors' calculations based on the survey

The need of raising ecological awareness was important for 85 and $82 \%$ of AES and non-AES respondents, respectively. Control and punishment for environmental pollution was not so important as the actions mentioned above. As much as $36 \%$ of non-AES dairy farmers did not have an opinion on this topic. The same subject was evaluated by Mroczek et al. [14]. Their studies were performed on a sample of farms chosen from the Agency for Restructuring and Modernisation of Agriculture's database located in Podkarpackie voivodship in 2012. Despite the fact that the period between the two surveys was 5 years, the introduction of financial support was also the most frequently chosen answer. But control and punishment was the second one. The necessity of education on environmental threats was pointed out only by $4 \%$ of AES farmers and $10 \%$ of non-AES producers in Mroczek et. al [14] research. In our opinion the significant difference in the needs of raising the ecological awareness between both studies comes from sample selection. Our questionnaire survey was performed among dairy producers, who are the most progressive group of farmers in Poland.

\section{General attitudes and values towards environment}

The results of the survey confirmed the popular view that involvement in AES schemes has increased the labour input in a farm (Table 6). It is proved by the data presented in Table 1. Half of the interviewed AES farmers agreed that implementation of environmental regulations lowers the farm income and $72.8 \%$ of non-AES farmers confirmed this statement. The view of these farmers is supported by the financial data shown in Table 1. Despite the fact that the total output of non-AES farms was higher by $33 \%$ in relation to AES farms, the difference in family farm income was only $3 \%$ in favour of non-AES holdings. It shows how big the influence of subsidies on family farm income is and confirms that payments in frame of environmental regulation are their key component. Our results confirm Hannley et al. [15] opinion that farming is perceived as a source of income through market opportunities, whereas AES as a regular revenue, is understood as a source of ecosystem services and an insignificant fund for further investment. The survey revealed a belief that environmental regulations are good for the future of agriculture, as expressed by 95.5 and $75 \%$ of non-AES and AES respondents, respectively. Up to $25 \%$ of the AES farmers did not have an opinion on this issue. Regarding the values related to environmental behaviour, the mean responses were higher for non-AES dairy farmers (Table 7). Further braking down the results shows that: for over $90 \%$ of non-AES farmers it is important to manage farms without damaging the environment and to make a profit, which was confirmed also by $85 \%$ of AES farmers. However, $90 \%$ of AES 
interviewees compared to $77 \%$ of non-AES stated that is important for them that the soil quality does not deteriorate.

Table 6

Responses showing farmers' attitudes towards environmental regulations (\%)

\begin{tabular}{|c|c|c|c|c|c|c|}
\hline \multicolumn{1}{|c|}{ Items } & $\begin{array}{c}\text { Strongly } \\
\text { disagree }\end{array}$ & Disagree & Neutral & Agree & $\begin{array}{c}\text { Strongly } \\
\text { agree }\end{array}$ & $\begin{array}{c}\text { Mean } \\
\text { (StDev) }\end{array}$ \\
\hline \multicolumn{7}{|c|}{ AES Dairy } \\
\hline $\begin{array}{c}\text { Environmental regulations } \\
\text { increase the farmer's work } \\
\text { input }\end{array}$ & 0.0 & 5.0 & 10.0 & 65.0 & 20.0 & $\begin{array}{c}4.00 \\
(0.73)\end{array}$ \\
\hline $\begin{array}{c}\text { Implementation of } \\
\text { environmental regulations } \\
\text { lowers farm income }\end{array}$ & 0.0 & 15.0 & 35.0 & 45.0 & 5.0 & $3.40(0.82)$ \\
\hline $\begin{array}{c}\text { Environmental regulations } \\
\text { are good for the future of } \\
\text { agriculture }\end{array}$ & 0.0 & 0.0 & 25.0 & 55.0 & 20.0 & $3.95(0.69)$ \\
\hline $\begin{array}{c}\text { Environmental regulations } \\
\text { increase the farmer's work } \\
\text { input }\end{array}$ & 0.0 & 9.1 & 36.4 & 40.9 & 13.6 & $\begin{array}{c}4.09 \\
(0.73)\end{array}$ \\
\hline $\begin{array}{c}\text { Implementation of } \\
\text { environmental regulations } \\
\text { lowers farm income }\end{array}$ & 0.0 & 9.1 & 18.2 & 36.4 & 36.4 & $\begin{array}{c}3.59 \\
(0.83)\end{array}$ \\
\hline $\begin{array}{c}\text { Environmental regulations } \\
\text { are good for the future of } \\
\text { agriculture }\end{array}$ & 4.5 & 0.0 & 0.0 & 9.1 & 86.4 & $\begin{array}{c}4.00 \\
(0.95)\end{array}$ \\
\hline
\end{tabular}

Source: authors' calculations based on the survey

Responses showing farmers' values related to environmental behaviour (\%)

Table 7

\begin{tabular}{|c|c|c|c|c|c|c|}
\hline Items & $\begin{array}{c}\text { Strongly } \\
\text { disagree }\end{array}$ & Disagree & Neutral & Agree & $\begin{array}{c}\text { Strongly } \\
\text { agree }\end{array}$ & $\begin{array}{c}\text { Mean } \\
\text { (StDev) }\end{array}$ \\
\hline \multicolumn{7}{|c|}{ AES Dairy } \\
\hline $\begin{array}{c}\text { It is important for me to } \\
\text { manage a farm without } \\
\text { damaging the environment } \\
\text { and to make a profit }\end{array}$ & 5.0 & 0.0 & 5.0 & 35.0 & 55.0 & $\begin{array}{c}4.35 \\
(0.99)\end{array}$ \\
\hline $\begin{array}{c}\text { It is important for me that } \\
\text { soil quality has not } \\
\text { deteriorated }\end{array}$ & 5.0 & 0.0 & 5.0 & 15.0 & 75.0 & $\begin{array}{c}4.55 \\
(1.00)\end{array}$ \\
\hline $\begin{array}{c}\text { It is important for me to } \\
\text { manage a farm without } \\
\text { damaging the environment } \\
\text { and to make a profit }\end{array}$ & 4.5 & 4.5 & 0.0 & 4.5 & 86.4 & $\begin{array}{c}4.73 \\
(0.86)\end{array}$ \\
\hline $\begin{array}{c}\text { It is important for me that } \\
\text { soil quality has not } \\
\text { deteriorated }\end{array}$ & 9.1 & 9.1 & 4.5 & 68.2 & 9.1 & $\begin{array}{c}4.64 \\
(1.02)\end{array}$ \\
\hline
\end{tabular}

Source: authors' calculations based on the survey

\section{Conclusions}

1. The study increased our understanding of dairy farmers' environmental awareness and how these views may be related to changes in agricultural practices. 
2. All surveyed farmers were characterized by high environmental awareness. This may result from the selection of a target sample based on the FADN database. It is assumed that the farmers, who participate in this system, have greater knowledge about agricultural production. Moreover, dairy farmers represent the most progressive producers within Polish agriculture.

3. There were no major differences between AES and non-AES respondents in the perception of environmental risks. The obtained results do not confirm the generally established view that farmers participating in AES are more aware of environmental threats because they complied with AES regulations.

4. This study indicates that above $80 \%$ of the surveyed farmers from both groups are increasingly interested in raising their ecological awareness in order to improve the state of environment.

5. Strengthening the ecological culture among farmers is one of the necessary conditions for building sustainable rural development. The role of the AES schemes in nature conservation will grow along with the inputs for their realization, therefore, their implementation has key importance for social reasons.

6. The research presented in this paper makes a contribution to the existing literature on the development of AES schemes

\section{Acknowledgements}

The studies have been supported by the project "New Strategies on Bioeconomy in Poland", which has received funding from the European Union programme HORIZON 2020, call: H2020 WIDESPREAD-2014-2, topic: WIDESPREAD-2014-2 ERA Chairs under grant agreement No 669062.

\section{References:}

[1] ARiMR (2015). Informacja o liczbie złożonych wniosków, liczbie i kwocie wydanych decyzji w ramach Działania „Program rolnośrodowiskowy PROW 2007-2013” Kampania 2015. [online][18.01.2019] Available at:

https://www.arimr.gov.pl/fileadmin/pliki/wdrazane_programy_sprawozdania/PROW_20072013/Rolnosrodowiskowe_/28122015_Rolnosrodowiskowe_7-13.pdf. (In Polish)

[2] EC.Science for Environment Policy. Agri-environmental schemes: how to enhance the agriculture-environment relationship. Thematic Issue 57,2017, Issue produced for the European Commission DG Environment by the Science Communication Unit. UWE. Bristol. [online][18.01.2019] Available at: http://ec.europa.eu/science-environment-policy.

[3] Batary P., Dicks L.V., Kleijn D., Sutherland W.J. The role of agri-environment schemes in conservation and environmental management. Conservation biology : the Journal of the Society for Conservation Biology, vol. 29, 2015, pp. 1006-1016.

[4] Hammes V., Eggers M., Isselstein J., Kayser M. The attitude of grassland farmers towards nature conservation and agri-environment measures - A survey-based analysis. Land Use Policy,vol.59, 2016, pp. 528-535.

[5] Wilson G.A., Hart, K., Financial imperative or conservation concern? EU farmers'motivations for participation in voluntary agri-environmental schemes. Environment and Planning A:Economy and Space, vol.32, 2000, pp. 2161-2186.

[6] Reimer, A.P., Prokopy, L.S. Farmer participation in U.S. Farm bill conservation programs. Environmental Management, vol. 53, 2014, pp. 318-332.

[7] Schroeder L.A., Isselstein J., Chaplin S., Peel S.. Agri-environment schemes: Farmers' acceptance and perception of potential 'Payment by Results' in grassland - A case study in England. Land Use Policy, vol. 32, 2013, pp. 134-144.

[8] CSO. Statistical Yearbook of the Regions - Poland.2017. Warszawa (In Polish)

[9] EC. Commission Regulation (EC) 1291/2009 of 18 December 2009 Concerning the Selection of Returning Holdings for the Purpose of Determining Incomes of Agricultural Holdings. Official Journal of the European Commission. (2009). Commission Regulation (EC) No 1291/2009 of 18 December 2009 concerning the selection of returning holdings for the purpose of determining incomes of agricultural holdings. No. 347, 2009, pp. 14-21. 
[10] Hejnowicz A.P., Rudd M.A., White P.C.L. A survey exploring private farm advisor perspectives of agri-environment schemes: The case of England's Environmental Stewardship programme. Land Use Policy, vol. 55, 2016, pp. 240-256.

[11] Woods B.A., Nielsen H.Ø., Pedersen A.B., Kristofersson D. Farmers' perceptions of climate change and their likely responses in Danish agriculture. Land Use Policy,vol. 65, 2017,pp. 109120.

[12] Drews S., van den Bergh, J.C.J.M., 2016. Public views on economic growth, the environment and prosperity: Results of a questionnaire survey. Global Environmental Change, vol. 39, pp. 1-14.

[13] van Dijk W.F.A., Lokhorst A.M., Berendse F., de Snoo G.R. Factors underlying farmers' intentions to perform unsubsidised agri-environmental measures. Land Use Policy, vol. 59, 2016, pp. 207-216.

[14] Mroczek J. R., Kostecka J., Korczyńska M. Ocena roli programu rolnośrodowiskowego w postrzeganiu przez rolników wybranych aspektów problematyki środowiskowej. Inżynieriaekologiczna, vol. 34, 2013, pp. 189-197. (In Polish)

[15] Hanley N., Whitby M., Simpson I. Assessing the success of agrienvironmental policy in the UK. Land Use Policy, vol. 16, 1999, pp. 67-80. 